\title{
Biological effect of functional nano-materials in various species of animals
}

\section{Vlizlo V. ${ }^{1}$, Fedoruk R. ${ }^{2}$, Iskra R. ${ }^{3}$}

Institute of biology of animals of NAAS, V. Stusa Str., 38, Lviv, 79034, Ukraine; e-mail: ${ }^{1}$ vasyl.vlizlo@inenbiol.com.ua, ${ }^{2}$ fedoruk@inenbiol.com.ua, ${ }^{3}$ ruslana_iskra@inenbiol.com.ua

The purpose. To find out biological impact of various concentration of nano-materials in an organism of animals and to determine perspectives of their use in animal husbandry. Methods. Physiological, biochemical, nano-technological with the use of biostatistical analysis. Results. Researchers are carried out on determining physiological and biochemical mechanisms of action of nano-aqua-citrates of microelements in an organism of cattle, pig, rabbit and bee during different periods of ontogenetic development and productive use. Effect is studied of these joints on the content in tissues and liquids of macro- and microelements, formation of immunobiological reactivity of an organism, state of anti-oxidant, detoxification, reproductive and immune systems, growth of calves, pigs and rabbits, as well as role of citrates in treatment and prophylaxis of microelementosis at animals. Functional changes of separate systems and organs of an animal of different species are determined at action of nano-materials on the basis of biotic elements and synthetic polymers. Series of biological effects with activation of living functions and biochemical processes in an organism of animals is revealed. Expediency of use of functional nano-materials as activators of exchange processes and efficient means of target delivery and magnification of therapeutic action of medical products is proved. Conclusions. Biological effect of different concentration of nano-materials in an organism of laboratory and productive animals is found out; their stimulating effect on metabolic processes in physiological doses is shown. It is established that citrates of microelements are biologically active and safe-health, and their application raises grow power and productivity of animals. Expediency of use of nanomaterials on the basis of citrates of bio-elements in animal husbandry is proved.

Key words: nano-technologies, nano-materials, medical products, animal, biotic elements, biological effect.

https://doi.org/10.31073/agrovisnyk201811-11

Modern studies have determined that nano- bio- materials for livestock must comply with such requirements as ecological purity, biocompatibility with this biological object, programmed productive action $[1,2]$.

With the help of nanotechnology, researchers obtained super-carboxy-lattices of the main food acids and biotic elements ( $\mathrm{Zn}, \mathrm{Mg}, \mathrm{S}, \mathrm{Mn}, \mathrm{Fe}, \mathrm{Cu}, \mathrm{Co}, \mathrm{Mo}, \mathrm{Cr}, \mathrm{I}, \mathrm{Se})$. A new direction for the enrichment of feed additives with microcells in the form of citrates of biotic elements obtained by the help of aqua-technology $[3,4]$ is developed.

The Institute of Animal Biology of the National Academy of Agrarian Sciences conducts research on the determination of physiological and biochemical mechanisms of the action of nanosized quasitates of trace elements in the organism of animals in different periods of ontogenetic development and productive use $[5,6]$. The toxic doses of nano-acacitrates of 20 elements, which turned out to be 6-8 times lower than their mineral salts have been determined. In this direction feed additives, veterinary drugs and drugs based on citrates of trace elements with high biological activity are developed [7]. Minimum physiologically active and optimal dosages for cattle, pigs, rabbits, bees are established. The influence of these compounds on the content in tissues and liquids of macro and microelements, formation of resistance of the organism, the state of antioxidant, reproductive and immune systems, growth and development of calves and rabbits are investigated. The influence of nanocaccurate elements of individual elements on the biological value of livestock products - milk, meat and honey has been studied. Certain differences in the effects of $\mathrm{Se}, \mathrm{Ge}, \mathrm{Cr}$, $\mathrm{Fe}$ in the organism of animals, in comparison with other compounds of these trace elements, have been established.

The purpose of the experiment. To find out the biological effects of various concentrations of nanomaterials in an organism of animals and determine the promising use of them in animal husbandry.

Materials and methods of research. The research was carried out on the experimental and laboratory basis of the IOAB using the number of animals of experimental and basic farms, as well as 
vivarium of the institute. In particular, the study of the biological effects of citrates of trace elements in cattle is conducted on the stock of cows and calves in the DPGD "Pasichna"; pigs - Progress Plus Ltd at Sukhovolia of Brody district of Lviv region and PP "Agroprodservice" of Ternopil region; rabbits - in the farms of the Mykolaiv and Horodok district of the Lviv region, rats and bees - the vivaria of the IBT. In animal studies used aqueous citrate trace elements - $\mathrm{Cr}$, Se, $\mathrm{Cu}, \mathrm{Co}, \mathrm{Fe}, \mathrm{Zn}, \mathrm{Ge}$, obtained by nanotechnology [7] nanopolimerni materials were synthesized at the University "Lviv Polytechnic". For laboratory studies, blood, milk, tissues of the internal organs, animal muscles were used. Determination of physiological and biochemical properties was carried out on the hematologic Mythic vet 18 (Switzerland) and biochemical Humalizer 2000 (Germany) analyzers.

Research results. In studies on cows, it was found that with the addition of $\mathrm{Cr}$, Se, Co, and $\mathrm{Zn}$ citrates, their liver function, the exchange of $\mathrm{Ca}, \mathrm{P}$ and vitamin $\mathrm{E}$ improved [8]. Inclusion in the diet of citrus cows of these elements contributed to the activation of metabolic processes in the body, an increase in catalase, superoxide dismutase and glutathione peroxidase activity at the 1 st and 2 nd months of supplementation (Fig. 1).
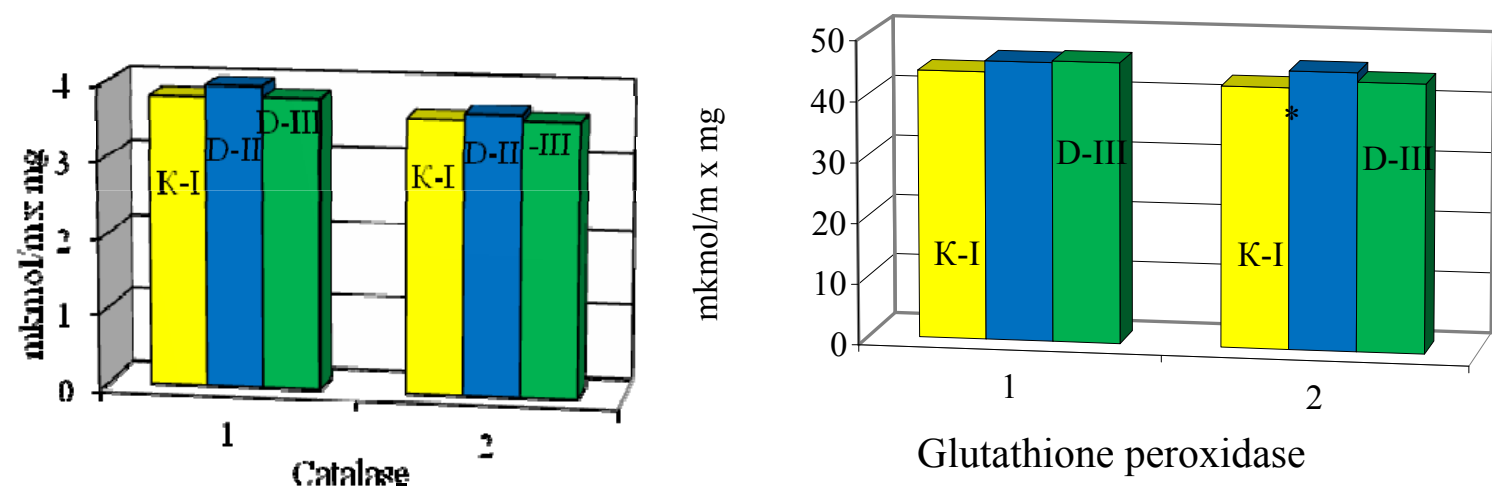

Glutathione peroxidase

Fig. 1. Enzyme activity of the antioxidant system of blood of cows during 2-month feeding of citrates (D-II) and mineral (D-III) elements.

Additives of micronutrient citrates stimulated secretory activity of the mammary gland, increased the daily milk yield of cows by $3.3-7.8 \%$ [9].

It has been proved that the ability of animals to reproduce and functional properties of male sperm depends on the content of trace elements that are active in the centrifugal enzymes of glycolysis, pentose phosphate pathway and antioxidant defense. In particular, the influence of citrums Mn2 +, Cu2 + and Zn2 + on the intensity of oxidative processes in semen and survival of bull sperm and bud was investigated. It was found that trace elements in the form of citrates penetrate into the cells of the cells and regulate the intensity of oxygen consumption and the ability of sperm, the activity of succinate dehydrogenase and survival of sperm in rarefied ejaculates of animals. Researchers recommend adding 10-, 20-fold lower doses of $\mathrm{Mn}$, Su and $\mathrm{Zn}$ citrates in order to balance the composition of dilution with the physiological limits of native ejaculates, normalize the oxidative metabolism and to ensure the long survival of sperm in the rarefied medium, compared with their analogues in form of salts [10].

In piglets during the period of weaning from sows, the expressed complex effect of trace elements $(\mathrm{Fe}$, $\mathrm{Zn}, \mathrm{Mn}, \mathrm{Cu}, \mathrm{Co}$ ) is 10 times higher than that of inorganic salts [11]. In particular, the activity of citrates of trace elements revealed an increase in the antioxidant activity of erythrocytes, which causes an increase in the adaptive properties of the organism during the period of the stress-factor of weaning of pigs. Increasing the number of erythrocytes and hemoglobin concentration due to the action of citrates of trace elements in pigs during this period is essential for the prevention of iron deficiency anemia. Activation of the hemopoiesis in the direction of intensifying the hemopoiesis process is obviously an adaptive response of the organism, which ensures the implementation of the protective function of the blood and promotes the formation of the immune status of animals in the early postnatal developmental period. Citers of trace elements increase this ability of the organism, affect the resistance and increase the resistance of animals to diseases during the period of weaning from sows. Consumption of pigs of tswaste of trace elements also affected the protein metabolism of the animals during the period of stress of weaning, in particular, contributed to the increase in the content of total protein and the decrease in the activity of alanine aminotransferase in their blood (Fig. 2). 

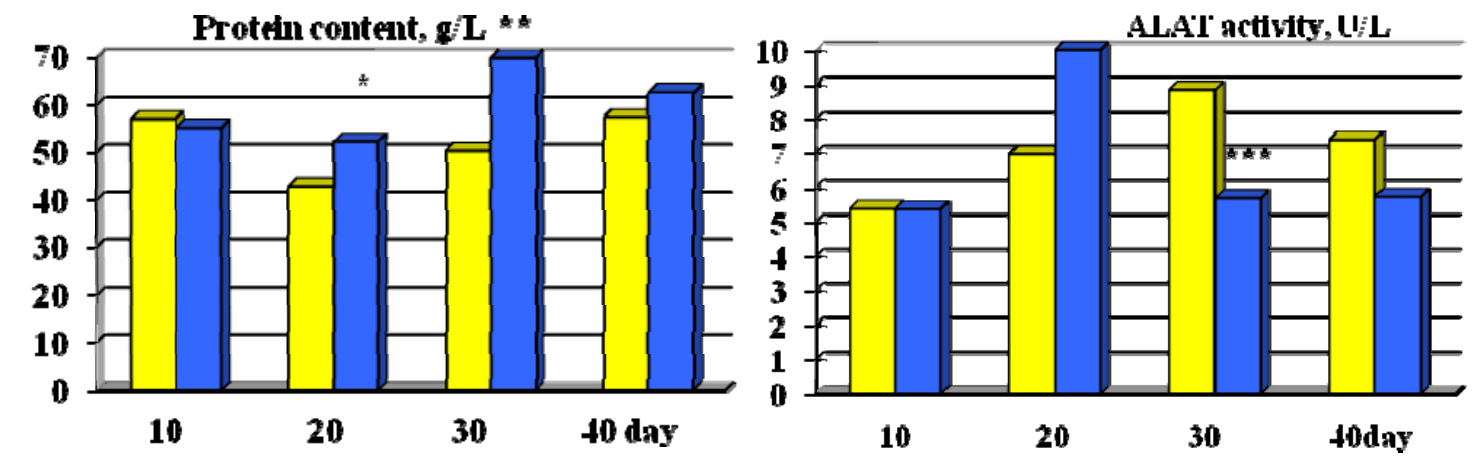

Fig. 2. Indices of exchange of proteins in blood plasma of piglets at weaning for the complex influence of citrates of trace elements $(M \pm m, n=10)$.

At the same time, a slight decrease in the concentration of glucose in the blood of piglets by the influence of citrates of trace elements on the 30th day of life is a positive effect due to the increased use of this substrate in their body as energy material during the duration of the stress factor of weaning. The obtained results are consistent with the literature data that certain microelements in citrate form have an effect on hormonal activity. Since Zinc regulates insulin secretion, and Chromium enhances its action by promoting binding of hormone to receptors on the cell surface, these elements affect the entire spectrum of insulin dependent processes [6]. Intensification of metabolic processes in the piglet organism due to the action of citrates of trace elements is due to the better assimilation of them, in comparison with inorganic salts. It was established that the use of citrates of trace elements in feeding pigs contributed to an increase of $33.6 \%$ of average daily increments in body weight, which was $131 \mathrm{~g}$ in the control group, while in the experimental group it was $175 \mathrm{~g}$ [11].

A comprehensive study of the effect of citrate ferrum on the fermentation and oxidative transport function of the blood and on the metabolic processes in the piglet organism have been carried out. The efficacy of this compound for the prevention of alimentary ferrum deficiency anemia has been proved. It was found that the introduction of citrate ferrum contributes to an increase in the number of erythrocytes and hemoglobin concentration in the blood, positively affects the ferment binding function of transferrin, stabilizes the blood proteins, the content of $\mathrm{Fe}, \mathrm{Cu}, \mathrm{Co}, \mathrm{Mn}$, vitamins $\mathrm{A}$ and $\mathrm{E}$, products of $\mathrm{LPO}$ and indicators of antioxidant system [12].

Citrules of trace elements that are consumed by females during pregnancy can affect metabolic processes not only in their body, but also in their fetuses and newborn offspring. It was established that chrome citrate, which was fed to sows for 10-15 days before delivery and for 20 days after delivery in doses of 0.5 and $2 \mathrm{~g} \mathrm{Cr}$ (III) / $\mathrm{kg}$ body weight, stimulated erythropoietic function as in pigs, and newborn piglets in the first days after delivery [13]. In addition, in the activity of chromium citrate in the amount of 2 $\mathrm{g} \mathrm{Cr}$ (III) / kg, the functional activity of leukocytes, the number of lymphocytes, and the level of segmental neutrophil granulocytes in the last month of pregnancy and in the first days after delivery increased in sows. This indicates an increase in the cellular level of nonspecific resistance, specific factors of protection, an increase in the reserve capacity of animals in the organism of the oxidative-reducing metabolic processes of leukocytes. Thus, changes in the hematopoietic and immunological parameters of blood of sows and newborn piglets for the introduction of chrome citrate into the diet, obviously, are adaptive reactions of their organism during the period of the stress factor - the birth.

In pregnant sows and the rabbit the correction of various metabolic pathways is carried out under the influence of chrome citrate, in particular the stabilization of carbohydrate, lipid and protein metabolism, and the antioxidant and immune systems of organs are normalized. Metabolic effective amounts of chrome citrate, which are additionally administered to animal diets, can be used as recommended doses for the regulation of metabolic processes and the prevention of $\mathrm{Cr}$ (III) deficiency in organism [6].

In rabbits the influence of chrome citrate, in the amount of $3 \mathrm{~g} / \mathrm{kg}$ body weight, on the parameters of $\mathrm{T}$ - and B-cell immunity was investigated. The increase in their blood relative to the content of common Tlymphocytes, T-active lymphocytes, T-helper cells, B-lymphocytes and the immunoregulatory index, indicating the activation of functional activity of lymphocytes and arousal of increased cellular and humoral neuronal immunity of rabbits for the action of chrome citrate (Fig. 3). 


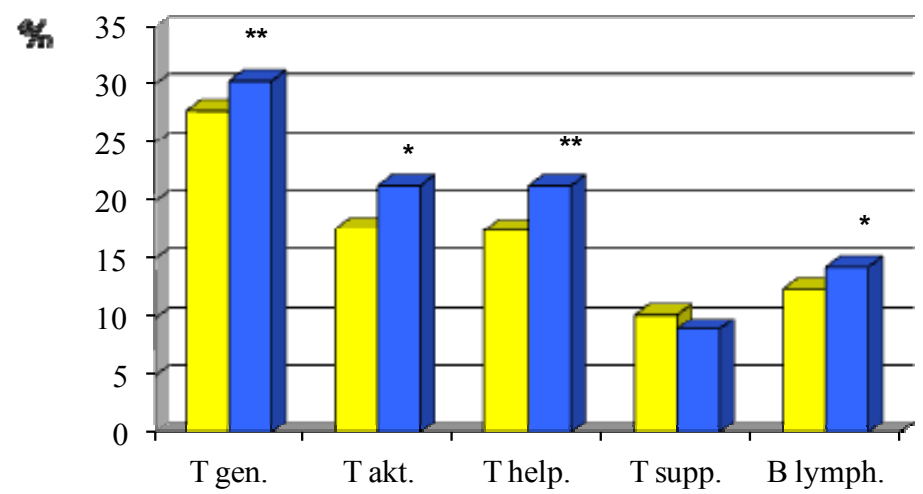

Fig. 3. Relative quantity of T- and B-lymphocytes in rabies blood at the influence of chrome citrate in a dose of $3 \mathrm{~g} / \mathrm{kg}(\mathrm{M} \pm \mathrm{m}, \mathrm{n}=4)$

Experimentally proved the high efficiency of chromium citrate activity in animal organs on carbohydrate, protein and lipid metabolism indices, activation of antioxidant, NO-synthase, endocrine and immune systems [6]. It was established that the introduction of citrate chromium into the diet of animals is accompanied by regulatory influence on the function of the adrenal, thyroid and parotid glands. In particular, it has been experimentally determined that by the action of chrome citrate, in the amount of 5 $\mathrm{g} \mathrm{Cr}$ (III) / kg body weight, in serum blood of rats, the insulin content tended to increase, the content of triiodothyronine increased by $53.1 \%$ and ty- of roxina - by $21.0 \%$, while the content of cortisol - decreased by $20.8 \%$ (Fig. 4). A similar effect, but much weaker, was shown in studies and inorganic-to-compound chromium chloride in the amount of $20 \mathrm{~g} \mathrm{Cr}$ (III) $/ \mathrm{kg}$.

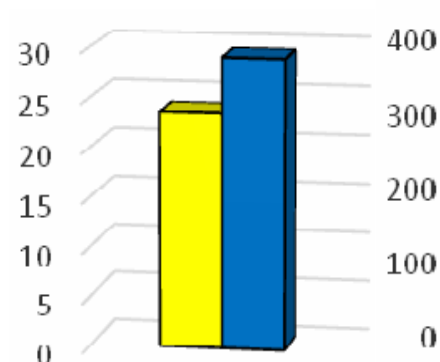

Insulin, $\mathrm{pmol} / \mathrm{L}$

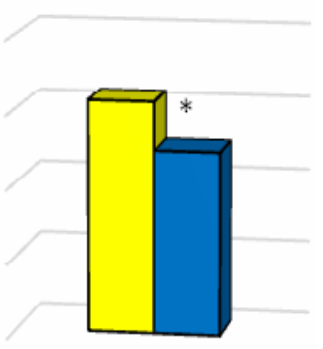

Cortisol, $\mathrm{nmol} / \mathrm{L}$

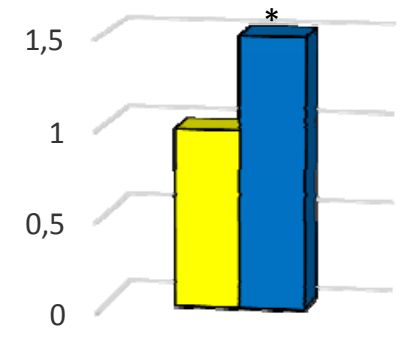

$\mathrm{T} 3 \mathrm{nmol} / \mathrm{L}$

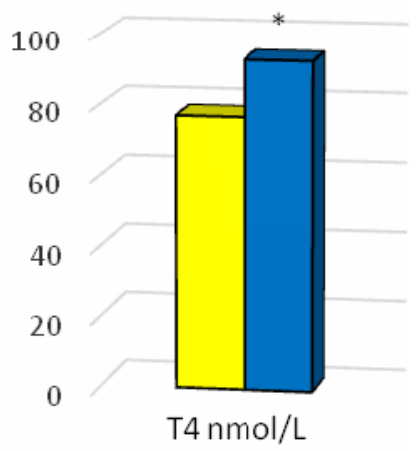

Fig. 4. The content of hormones in blood serum of rats for the action of chrome citrate in the amount of $5 \mathrm{~g} \mathrm{Cr}$ (III) / kg.

The disintoxication function and activity of antioxidant enzymes in blood and tissues of laboratory animals for the distribution of $\mathrm{Cr}$, Se and $\mathrm{Ge}$ Citrits to female mothers was investigated [14]. Positive dose-dependent $(10,20,200 \mathrm{~g}$ Ge / $\mathrm{kg} \mathrm{m}$. T) positive effect of Gez citrate on the growth and development of the organism of rats, its hematological and immuno-physiological parameters [15].

It is proved that "nanocaccurate" of mineral elements is not only biologically active but also safe for health and is allowed for the enrichment of feed, raw materials and food products and exhibits tread properties for heavy metals [4]. Thus, for the use of $\mathrm{Cr}$, Se, Co and $\mathrm{Ge}$ citrates for feeding bees, a decrease in the content of heavy metals $(\mathrm{Cd}, \mathrm{Pb})$ was found in both tissues of the whole organism (Fig. 5) and in individual anatomical units of bees. This ensures that they increase their vitality, increase the 
content in the organism and promote beekeeping of essential micronutrients, lipid and carbohydrate compositions.

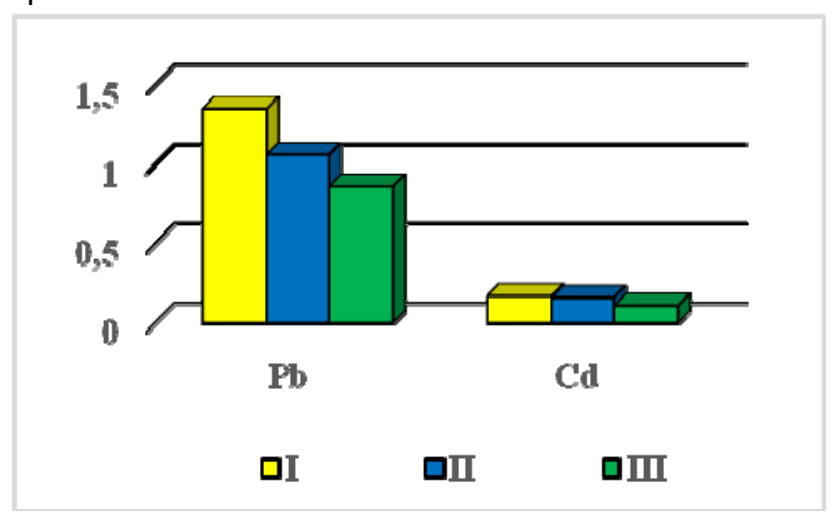

Fig. 5. The content of $\mathrm{Pb}$ and $\mathrm{Cd}$ in the tissues of bee organsis, $\mathrm{mg} / \mathrm{kg}$.

The dynamics of the content of lipids in bees' tissues is established, which contributes to the processes of metabolic accumulation of energetic and plastic components. The obtained data confirm the expediency of using additives of citrates of trace elements in feeding bees.

The influence of separate and common use of different doses of cyto-ratites of $\mathrm{Co}$ and $\mathrm{Ni}$ in the spring supplement for honeybees on the intensity of egg laying with bees uterus was investigated. The obtained research results indicate a significant stimulating effect of Citrates $\mathrm{Co}$ and $\mathrm{Ni}$ in their separate application on the intensity of oviposition of bees in the spring [16].

Scientists create and use in the research polymer carriers of pseudopolymino acids for the delivery of biologically active substances. In particular created a nanoplomer GluLa-DPG-PEG600, which contains in its composition glutamic and lauric acid, dipropylene glycol, polyethylene glycol. By electrophoresis in $5 \%$ polyacrylamide gel, the ability of GluLa-DPG-PEG600 to bind serum albumin to blood [17] is established. This is a positive characteristic of this polymer as a potential transporter for proteins and drugs, in particular for the creation of vaccines.

\section{Conclusions}

The biological effect of various concentrations of nanomaterials in the organism of laboratory and productive animals is revealed; stimulating effect on metabolic processes in physiological doses is shown. It has been established that the citrate of trace elements is biologically active and safe for health, and their application leads to increased animal vitality and productivity. Based on this, the expediency of using nanomaterials based on citrates of bioelements in animal husbandry has been substantiated.

In the long term it has been considered expedient to continue the research on the use of trace elements and synthetic polymers in livestock, as biologically active and animal-safe animal compounds.

\section{References}

1. Hill E.K., Li Ju. (2017). Current and future prospects for nanotechnology in animal production. J. Anim Sci Biotechnol. No 8. P. 26. doi: 10.1186/s40104-017-0157-5.

2. Jennifer Kuzma. (2010). Nanotechnology in animal production - Upstream assessment of applications. Livestock Science. No 130(1 - 3). P. $14-24$.

3. Kaplunenko V.H., Avdosieva I.K., Pashchenko A.H. (2014). Realni perspektyvy vykorystannia zdobutkiv nanotekhnolohii u veterynarnii praktytsi. [Realistic prospects for using nanotechnology gains in veterinary practice]. Naukovo-tekhnichnyi biuleten DNDKI vetpreparativ i kormovykh dobavok ta Instytutu biolohii tvaryn. No 15(4). P. 252 - 260. [In Ukrainian].

4. Serdiuk A.M., Hulich M.P., Kaplunenko V.H., Kosinov M.V. (2010). Nanotekhnolohii mikronutriientiv: problemy, perspektyvy ta shliakhy likvidatsii defitsytu makro- ta mikroelementiv. [Nanotechnologies for micronutrients: problems, prospects and ways of eliminating the deficit of macro- and micronutrients]. Visnyk akademii medychnykh nauk. No 1. P. 107 - 114. [In Ukrainian].

5. Vlizlo V.V., Iskra R.la., Fedoruk R.S. (2015). Nanobiotekhnolohii, suchasnist ta perspektyvy rozvytku. [Nanobiotechnology, modernity and development perspectives]. Biolohiia tvaryn. No 17(4). P.18 - 29. [In Ukrainian]. 
6. Iskra R.Ia., Vlizlo V.V., Fedoruk R.S., Antoniak H.L. (2014). Khrom u zhyvlenni tvaryn: monohrafiia. [Chromium in animal nutrition: monograph]. Kyiv: Ahrarna nauka. 312 p. [In Ukrainian].

7. Borysevych V.B., Borysevych B.V., Kaplunenko V.H. (Borysevych V.B., Kaplunenko V.H. Eds.). (2009). Nanotekhnolohiia u veterynarnii medytsyni. [Nanotechnology in veterinary medicine]. Kyiv: Lira. 232 p. [In Ukrainian].

8. Fedoruk R.S., Khomyn M.M., Kovalchuk I.I., Khrabko M.I. (2014). Dezintoksykatsiini protsesy i biokhimichnyi profil krovi ta moloka koriv za zghodovuvannia tsytrativ selenu, khromu, kobaltu i tsynku. [Disinfection processes and biochemical profile of blood and milk of cows for feeding of citrates of selenium, chromium, cobalt and zinc]. Bioresursy i pryrodokorystuvannia. No 6(3-4). P. 98 - 103. [In Ukrainian].

9. Khomyn M.M., Fedoruk R.S., Kropyvka S.I. (2015). Biokhimichni protsesy v orhanizmi koriv i biolohichna tsinnist moloka za vplyvu tsytrativ khromu, selenu, kobaltu ta tsynku. [Biochemical processes in the body of cows and the biological value of milk due to exposure to chromates, selenium, cobalt and zinc citrates]. Biolohiia tvaryn. No 17(1). P. 155 - 162. [In Ukrainian].

10. Yaremchuk I.M., Bodnar Yu.V., Kuzmina N.V. et al. (2016). Intensity of oxidative processes and quality of bulls' sperm by adding in trace elements of trace elements. Biochemical processes in the body of cows and the biological value of milk due to exposure to chromates, selenium, cobalt and zinc citrates. No $17(2)$. P. $88-94$.

11. Iskra R.la. (2017). Pro vplyv tsytrativ mikroelementiv na metabolizm v orhanizmi porosiat u period vidluchennia vid svynomatok. [On the effect of citrates of trace elements on the metabolism of piglets in the period of weaning from sows]. Ukrainskyi fermer.No 1(85). P. 152 - 153. [In Ukrainian].

12. Vlizlo V., Iskra R., Maksymovych I., Berezovskyy R. (2014). The system of erythrocyte antioxidant protection in piggeryas affected by ferrous citrate. British Journal of Science, Education and Culture. No 8. 1(5). P. $44-49$.

13. Iskra R.la. (2011). Fizioloho-biokhimichni osoblyvosti krovi svynomatok i novonarodzhenykh porosiat za vplyvu tsytratu nanokhromu. [Physiological and biochemical features of blood of sows and newborn piglets under the influence of nanocryane citrate]. Naukovi zapysky Ternopilskoho natsionalnoho pedahohichnoho universytetu. Seriia: biolohiia. No 4(49). P. 103 - 108. [In Ukrainian].

14. Fedoruk R.S., Khomyn N.M., Khomyn M.M. (2013). Fizioloho-biokhimichnyi vplyv tsytrativ nanochastynok khromu ta selenu $v$ orhanizmi shchureniat. [Physiological and biochemical influence of chrome and selenium nanoparticle citrates in the organism of rats]. Biolohiia tvaryn. No 15(4). P. $141-$ 149. [In Ukrainian].

15. Khrabko M.l., Fedoruk R.S. (2016). Rist i rozvytok orhanizmu samtsiv shchuriv $\mathrm{f} 1$ ta yoho imunofiziolohichna aktyvnist u period vypoiuvannia riznykh doz nanotekhnolohichnoho i khimichno syntezovanoho tsytratu hermaniiu. [Growth and development of the body of male rats $\mathrm{f} 1$ and its immunophysiological activity during the presentation of various doses of nanotechnological and chemically synthesized germanium citrate]. Biuleten Kyivskoho natsionalnoho universytetu imeni Tarasa Shevchenka. Seriia: problemy rehuliatsii fiziolohichnykh funktsii. № 21(2). P. 39 - 43. [In Ukrainian].

16. Fedoruk R.S., Pashchenko A.G., Kovalchuk I.I., Romaniv L.I. (2016). The intensity of egg laying by bee uteri in the spring when fed to their families of $\mathrm{Co}$ and Ni citrates with sugar syrup. Scientific symposium with international participation dedicated to 60th anniversary of the founding of the Institute "Zootechnycal science - an important factor for the european type of the agriculture» 29 september 01 octomber Maximovca. P. $774-779$.

17. Vlizlo V.V., Zaichenko O.S., Ivanytska L.A. et al. (2013). Definition deoxynucleotide oligo complexes with polymer carriers. Biotechnologia acta. V. 6. No 5. P. $94-99$. 